\title{
RECENZJA
}

„Studia Wyborcze”, tom 29, 2020

DOI: https://doi.org/10.26485/SW/2020/29/6

\section{MARCIN GRZYBOWSKI, WOLNOŚĆ WYPOWIEDZI A OCHRONA DÓBR OSOBISTYCH I PRYWATNOŚCI UCZESTNIKÓW MEDIALNYCH KAMPANII WYBORCZYCH W STANACH ZJEDNOCZONYCH AMERYKI, Dom Wydawniczy Elipsa, Warszawa 2018, ss. 314}

Prowadząc badania naukowe, natrafiłem na niezwykle interesującą publikację autorstwa Marcina Grzybowskiego pt. Wolność wypowiedzi a ochrona dóbr osobistych i prywatności uczestników medialnych kampanii wyborczych $w$ Stanach Zjednoczonych Ameryki. Monografia została wydana przez Dom Wydawniczy ELIPSA w Warszawie, w 2018 roku. Zdecydowałem się na napisanie recenzji tej pozycji z kilku powodów.

Po pierwsze, ze względu na aktualność poruszanej tematyki. Od kilku lat na świecie obserwuje się brutalizację debaty politycznej, w szczególności tej medialnej. Taki stan rzeczy powoduje obniżanie się standardów kampanijnych, chociażby przez naruszenie właściwego ich przebiegu, a także uczciwości całego procesu wyborczego. Po drugie, polska literatura prawnicza dotycząca wolności wypowiedzi w amerykańskim prawie federalnym i stanowym nie jest szczególnie bogata, mimo istniejących pewnych opracowań na ten temat ${ }^{1}$. Ponadto, autorzy istniejących publikacji skupiają się jedynie na niektórych jej aspektach, tj. analizie Pierwszej Poprawki do Konstytucji Stanów Zjednoczonych oraz orzecznictwa Sądu Najwyższego Stanów Zjednoczonych. Recenzowana monografia wypełnia więc tę lukę w polskiej doktrynie prawa. Po trzecie, niektóre problemy badawcze poruszone $\mathrm{w}$ tej publikacji są zbieżne $\mathrm{z}$ moimi zainteresowaniami naukowymi.

$\mathrm{Na}$ wstępie należy stwierdzić, że recenzowana monografia stanowi pozycję interdyscyplinarną, zawierającą rozważania nie tylko z dziedziny prawa (m.in. cywilnego, konstytucyjnego i mediów), ale także z dziedziny nauk politycznych. Jest to

\footnotetext{
${ }^{1}$ Pisali na ten temat m.in. Ł. Machaj (Wypowiedzi symboliczne w orzecznictwie Sąu Najwyższego USA, Wrocław 2011) i J. Skrzydło (Wolność słowa w orzecznictwie Sadu Najwyższego Stanów Zjednoczonych i Europejskiego Trybunału Praw Człowieka. Analiza porównawcza, Toruń 2013).
} 
nowatorskie i całościowe ujęcie niezwykle istotnej problematyki konfliktu wartości: wolności wypowiedzi z prawami podmiotowymi jednostki (w tym prawa do prywatności) w kontekście medialnych kampanii wyborczych na gruncie amerykańskiego systemu prawnego.

Wymaga podkreślenia, że poruszanie wielu wątków o charakterze interdyscyplinarnym zawsze niesie ze sobą ryzyko, że treść w ten sposób przygotowanego opracowania stanie się chaotyczna i odbiegać będzie od głównego problemu badawczego postawionego na wstępie. $\mathrm{W}$ tym przypadku jednak wywody autora zostały przeprowadzone w sposób logiczny i uporządkowany, a syntetyczny sposób przekazywania wiedzy nie spowodował wyżej wspomnianego chaosu. Język rozprawy przystaje do badanej dziedziny oraz rangi opracowania. Jest on staranny i precyzyjny. Na szczególne podkreślenie zasługuje dobry warsztat naukowy autora, szerokie widzenie problemu, który jest przedmiotem jego dociekań naukowych oraz wnikliwe podejście do analizy materiału badawczego, co jest zapewne wynikiem jego doświadczeń nie tylko jako teoretyka, ale i praktyka prawa.

Opracowanie składa się z wprowadzenia, pięciu rozdziałów dzielonych na podrozdziały, uwag końcowych, spisu diagramów i tabel oraz bibliografii.

We wprowadzeniu autor wskazuje, że proces wykorzystania mediów elektronicznych nastąpił najwcześniej w Stanach Zjednoczonych i tam też poczynił największe postępy. To właśnie sądy amerykańskie oraz tamtejsza doktryna prawa zmierzyły się z konsekwencjami zmienionej formy kampanii wyborczej najwcześniej i w największej liczbie przypadków.

Pierwszy i trzeci rozdział monografii mają charakter historyczno-opisowy oraz politologiczny, a drugi, czwarty i piąty dogmatycznoprawny i historyczno-prawny.

W pierwszym rozdziale autor przedstawia proces kształtowania się mediów elektronicznych jako formy prowadzenia kampanii wyborczej w Stanach Zjednoczonych. Po pobieżnym przedstawieniu tradycyjnych mediów elektronicznych, będących narzędziami kampanii wyborczej, autor przechodzi do omówienia Internetu, który jest uznawany za nowy rodzaj mediów. Dalsze rozważania prezentują skalę zjawiska korzystania z mediów elektronicznych przez uczestników kampanii wyborczych w konkretnym rodzaju wyborów (prezydenckich oraz do Senatu i Izby Reprezentantów Stanów Zjednoczonych). Pierwszy rozdział kończy się rozważaniami na temat roli mediów elektronicznych w kampaniach wyborczych. Postawione zostało pytanie retoryczne, czy rolą tych środków przekazu jest dostarczanie informacji uczestnikom kampanii, czy wręcz przeciwnie, sterowanie zachowaniem jej uczestników, tj. wyborców.

Drugi rozdział dotyczy odpowiedzialności za rozpowszechniany przez media przekaz w świetle standardów wyznaczonych przez prawo wyborcze federalne i stanowe oraz orzecznictwo sądowe. W dalszej części drugiego rozdziału autor dokonał analizy wolności wypowiedzi wyborczej medialnej przez pryzmat kilku 
aktów prawnych, tj. kolejno: pierwszej poprawki, federalnej ustawy o działalności nadawczej z 1993 roku, federalnej ustawy o łączności z 1934 roku, federalnej ustawy o kampanii wyborczej z 1971 roku. Autor swoje wywody prezentuje w sposób przekonujący i spójny. Należałoby jedynie zastanowić się, czy analiza regulacji prawa konstytucyjnego i federalnego (rozdz. 2, podrozdz. 2) nie powinna poprzedzać analizy prawa stanowego (rozdz. 2, podrozdz. 1). Wywód przeprowadzony w tej części książki wzbogacają liczne odniesienia politologiczne.

Trzeci rozdział pracy należy traktować jako rozwinięcie problematyki poruszanej w rozdziale pierwszym. Autor bardzo szczegółowo i z precyzyjna chronologią prezentuje ewolucję wykorzystania Internetu jako środka komunikowania się w amerykańskich kampaniach wyborczych, począwszy od lat 60 . XX wieku na 2016 roku skończywszy.

W czwartym rozdziale monografii autor poddał analizie kwestie ochrony dóbr osobistych uczestników medialnych kampanii wyborczych w Stanach Zjednoczonych. Rozważania rozpoczął od przedstawienia zasad ochrony dóbr osobistych oraz środków prawnych dochodzenia tej ochrony. Dokonał tego m.in. poprzez bardzo staranne przeanalizowanie orzecznictwa sądowego $\mathrm{w}$ tym zakresie. Ogromnym walorem pracy jest opracowanie zestawienia „uregulowań stanowych służących zagwarantowaniu uczciwej kampanii wyborczej” (s. 166-169). Przedstawiciele amerykańskiej doktryny prawa wyborczego określają te przepisy prawa stanowego terminem ,praw przeciwdziałających fałszywym twierdzeniom” (candidate false statement laws, CFSL). To, czego zabrakło w monografii, to rozważań na temat podejścia orzecznictwa Sądu Najwyższego Stanów Zjednoczonych i sądów stanowych w kwestii zgodności tych praw z pierwszą poprawką. Należy jednak podkreślić, że nie pojawiło się w polskiej nauce prawa wyborczego żadne opracowanie omawiające CFSL ani w formie artykułu, rozdziału, czy tym bardziej monografii, dlatego też to pominięcie nie może być poczytane jako wada. Czwarty rozdział kończą politologiczne rozważania na temat rodzajów wypowiedzi formułowanych podczas kampanii wyborczej (satyry, parodii i karykatury), a także negatywnej kampanii w mediach elektronicznych.

Rozważania poczynione w ostatnim, najobszerniejszym rozdziale, liczącym prawie 100 stron, dotyczą ochrony prawa do prywatności uczestników medialnej kampanii wyborczej. Przeprowadzona przez autora analiza sprowadza się do imponującego, bo zawartego prawie na 80 stronach, wywodu omawiającego prawo podmiotowe przysługujące uczestnikom kampanii do ochrony prywatności. Autor zastanawia się nad przesłankami i zasadnością dochodzenia roszczeń $\mathrm{z}$ tego prawa, gdy popadnie ono $\mathrm{w}$ konflikt $\mathrm{z}$ silnie chronioną wolnością słowa. Badając to zagadnienie, analizowano nie tylko treść aktów prawnych, takich jak Konstytucja USA, ustawa o prywatności z 1974 roku, ustawa o ochronie prywatności w komunikacji elektronicznej z 1986 roku, ustawa McCeina i Feingolda z 2002 roku, ale także orzecznictwo Sądu Najwyższego USA, sądów stanowych, 
w tym stanowych sądów najwyższych. Wiele uwagi autor poświęca także amerykańskiej doktrynie ,prawa do prywatności” opracowanej już w 1890 roku przez Samuela Warrena i Louisa Brandeisa.

W uwagach końcowych autor podsumował swoje dotychczasowe wywody i sformułował kilka bardzo ważnych szczegółowych wniosków. Po pierwsze stwierdza, że amerykański system ochrony dóbr osobistych osób fizycznych opiera się w przeważającej mierze na regulacjach prawa stanowego i federalnego, a także orzecznictwie sądowym. Ochrona ta w odniesieniu do uczestników kampanii wyborczych powinna być postrzegana w dwóch aspektach, tj. jako forma zabezpieczenia poszczególnych dóbr osobistych jako czynników determinujących podmiotowość społeczną i respektująca autonomię jednostki oraz jako forma minimalizowania rywalizacji personalnej (wzajemne oskarżenia i ataki) kosztem zwiększenia rywalizacji merytorycznej (prezentacja poglądów i programów kandydatów). Po drugie, poddaje pod rozwagę kwestię, czy specyfika medialnych naruszeń dóbr osobistych i prywatności kandydatów uzasadnia ustanawianie specyficznych sankcji (model oparty na odpowiedzialności deliktowej) za kampanijne naruszenia tych dóbr. Po trzecie stwierdza że, rozpowszechnianie informacji podczas kampanii wyborczych w formie tradycyjnej (prasa, radio, telewizja) oraz odpowiedzialność za powyższe, różnią się od informacji rozpowszechnianej za pomocą mediów elektronicznych. Przedstawione wyżej wnioski, jak i te pozostałe wyszczególnione w uwagach końcowych, autor prezentuje w przekonujący sposób, odwołując się do argumentów teoretycznoprawnych, ale i politologicznych. Wszystkie one należy uznać za w pełni zasadne.

Podsumowując, uważam, że recenzowany tom jest publikacją wartościową i zasługuje na duże uznanie, a także stanowi cenny wkład w dziedzinę polsko-amerykańskiego prawa porównawczego. Ponadto autor dokonał krytycznej analizy poglądów prezentowanych w światowej nauce prawa. Korzystał w z obszernej literatury obcojęzycznej, co sprawia, że treści zawarte w publikacji niosą ze sobą znaczny wkład w rozwój polskiej nauki. Uniwersalność przekazu, interdyscyplinarność tematyki poruszanej $\mathrm{w}$ monografii oraz dobór ciekawych i wnikliwie omówionych przykładów powoduje, że opracowanie to będzie przydatne nie tylko dla teoretyków prawa, ale też dla praktyków czy politologów lub historyków. 